regional authorities who have made bulldozers available free of charge.

The Red Cross of Can-Tho has opened two milk stations, financed by the League. The powdered milk has been supplied by various voluntary agencies. A sewing room with six sewing machines provided by the League will operate under the direction of Red Cross women volunteers, who will give basic instruction in dressmaking.

Finally, the "Henry Dunant I", the first vessel of a flotilla of small boats flying the Red Cross flag, will soon be sailing the Delta canals. With an out-board motor and a long horizontal pole, she is able to thread her way along the smallest waterways right up to lonely hamlets inaccessible by road. The "Henry Dunant I" is a narrow vessel some 20 feet in length with a very shallow draught. Made of wood, and covered by a waterproof straw roof, which is painted with a large red cross, she can carry four persons and medicaments as well as a folding stretcher. She was built in Rach-Gia by a boat builder according to the traditional methods of the Deita.

This is the first mobile floating dispensary in Viet-Nam. Other boats will be acquired as the needs arise.

\title{
RED CRESCENT HELP TO PILGRIMS
}

Vast numbers of pilgrims go to the Mecca and it is obvious that when so many people are grouped together a serious sanitary problem arises. As has been mentioned in a previous issue, the Seminar of North African and Middle East National Societies, at Rabat in May 1966, considered this question and in its Resolution No. VIII pointed out "the responsibilities which National Red 


\section{IN THE RED CROSS WORLD}

Crescent Societies can assume in order to meet the sanitary, social and humanitarian needs of pilgrims" 1 .

Conditions have been considerably improved for pilgrims according to a news release by the League of Red Cross Societies at the beginning of April 1967; we believe the text thereof will be of interest to our readers:

The constant efforts on the part of the Saudi Arabian government authorities and the Red Crescent Society to preserve and improve the health of the population and the pilgrims going to Mecca, are beginning to bear fruit. Mr. Nedim Abut, Deputy Secretary General of the League of Red Cross Societies, reported upon his return to Geneva from Saudi Arabia, Kuwait and Tunisia.

Not a single case of dangerous communicable disease was detected among the $1,500,000$ pilgrims who recently made the annual trek to the Moslem holy places, said Mr. Abut.

" On the personal invitation of His Majesty King Faisal of Saudi Arabia, I had the privilege to witness personally the tremendous efforts being made by Government health authorities, the Saudi Arabian Red Crescent Society, the medical teams of this Society as well as those from the Turkish Red Crescent and the Red Lion and Sun Society of Iran, to care for the health and welfare of the pilgrims", declared Mr. Abut.

The year-round Red Crescent ambulance services and first-aid posts are on permanent duty along the pilgrimage route and at the holy places, he said. In addition, the Red Crescent maintains an intensive programme of first-aid training for members of the public services. In the last months of $1966,3,000$ public servants took these courses.

${ }^{1}$ See International Review, August 1966. 